\title{
KAJIAN VALIDITAS KLAIM CHINA ATAS WILAYAH LAUT CINA SELATAN INDONESIA
}

\author{
Patrisius Bagus Alvito Baylon, Octavianus Bagaswara Adi, Linquinn Aiko, Inditha \\ Roulina Silalahi, Satrio Hasian Sitanggang, Dimas Naufal Al Ghifari, Bernard Susanto, \\ Laode Muhammad Syarifizal, Alfiannisa Nur Afifah, Qoulan Thoyyibah Sulaiman \& Epin \\ Saepudin \\ Institut Teknologi Bandung \\ Email : patrisiusvito@gmail.com
}

\begin{abstract}
Abstrak
Lewat nine dash line, China melakukan klaim atas wilayah Laut China Selatan, termasuk di dalamnya meliputi wilayah Indonesia. Dampak dari klaim tersebut adalah peningkatan aktivitas China di Laut China Selatan, seperti meningkatnya aktivitas kapal-kapal China di wilayah laut Indonesia. Penelitian ini bermaksud untuk melihat validitas klaim China atas wilayah Indonesia di Laut China Selatan. Klaim China didasarkan pada klaim historis berdasarkan aktivitas kelautan nelayan tradisional China di wilayah tersebut. Dalam mengatur wilayah yuridiksi di laut, terdapat hukum internasional untuk mengaturnya, yakni United Nation Convention on The Law of The Sea. Dalam hukum tersebut, telah diatur bahwa suatu negara berhak atas beberapa wilayah laut, seperti Zona Ekonomi Ekslusif, Landas Kontinen, dan Laut Teritorial. Klaim dan aktivitas yang dilakukan China di wilayah Laut China Selatan merupakan pelanggaran terhadap berapa pasal dalam UNCLOS sekaligus pelanggaran terhadap kedaulatan Indonesia yang memiliki hak atas wilayahnya di laut tersebut, beserta dengan sumber daya di dalamnya.
\end{abstract}

Kata kunci: Laut China Selatan, UNCLOS, Indonesia, China

\begin{abstract}
China claims the majority of the South China Sea as their territory using nine-dash line, including Indonesia's sea territory. To strengthen the claim, China increases its activity in the region by sending its ships into Indonesia's territory. China's claims over the region are based on a historical claim from their traditional fishermen's activity in that area. There is international law to regulate jurisdiction areas in the sea, such as The United Nations Convention on The Law of The Sea. The document regulates that a nation has a right over sea territories, such as Exclusive Economic Zone, Continental Shelf, and Territorial Sea. China's claim and activity over the region are a violation to several clauses in the UNCLOS and Indonesia's sovereignty over the region, including are the resources in it.
\end{abstract}

Keywords: South China Sea, UNCLOS, Indonesia, China

\section{PENDAHULUAN}

Indonesia sebagai salah satu negara kepulauan terluas di dunia terdiri dari ribuan pulau, salah satunya adalah Kepulauan Natuna yang posisinya menjorok ke utara di Laut Cina Selatan. Kawasan Laut Cina Selatan yang merupakan jalur pelayaran strategis dunia dan kaya akan sumber daya alam memiliki nilai aset yang sangat tinggi sehingga menyebabkan berbagai macam persaingan dalam ruang lingkup kawasan atau regional. Selama beberapa dekade, terjadi ketegangan antara Tiongkok dan negaranegara ASEAN mengenai Laut China Selatan yang masih menimbulkan sengketa. Indonesia sendiri menjadi salah satu Negara yang terkena dampak dari konflik ini karena wilayah ZEE (Zona Ekonomi Eksklusif) Indonesia di wilayah Perairan Natuna masuk dalam peta klaim sepihak China.

Laut Natuna Utara kerap kali menjadi sumber konflik antara Indonesia dengan China karena kedua negara samasama memiliki pengakuannya sendiri 
terhadap wilayah tersebut. Indonesia mengakui bahwa wilayah tersebut merupakan Zona Ekonomi Eksklusif-nya berdasarkan UNCLOS 1982 dan berhak untuk melakukan kegiatan ekonomi pada wilayah perairan tersebut. Di sisi lain, China tidak mengakui UNCLOS 1982 dan mengatakan bahwa perairan tersebut berada pada Nine Dash Line miliknya sehingga China merasa berhak melakukan patroli dan menempatkan kapal perang dan kapal coast guard mereka di sana. Kedua pengakuan ini menyebabkan berbagai polemik dalam kehidupan seharihari masyarakat yang memanfaatkan perairan tersebut sebagai mata pencaharian mereka seperti nelayan dan industri pertambangan, juga menimbulkan masalah sosial-politik kedaulatan Indonesia sendiri.

Berkaca dari masalah tersebut, penelitian ini ditujukan untuk menganalisis kepantasan negara Indonesia dalam mengklaim wilayah Perairan Natuna berdasarkan hukum-hukum yang sudah ada. Penulis ingin meninjau legitimasi klaim kedua negara atas wilayah Laut Natuna Utara berdasarkan pandangan internasional.

Sepanjang sejarah, laut telah menjadi bagian penting dari kehidupan umat manusia. Meningkatnya penggunaan laut dalam kehidupan sehari-hari membuat perlunya ada aturan internasional yang mengatur berbagai kegiatan manusia di laut. Dari situlah lahir The Law of The Sea (Hukum Laut).

Dalam hubungan internasional, Hukum Laut memiliki fungsi ganda. Fungsi pertama dan utama dari Hukum Laut adalah distribusi spasial dari yurisdiksi negara-negara. Hukum Laut membagi lautan ke dalam beberapa zona yurisdiksi, seperti Zona Ekonomi Eksklusif, zona landas kontinen, dan laut teritorial. Hukum Laut memberikan hak kepada negaranegara kedaulatan pada zona-zona tersebut dan hak untuk mengelola sumber daya yang ada di dalamnya. Jika fungsi pertama tadi seakan membagi lautan ke dalam zona-zona, fungsi kedua Hukum Laut memandang laut sebagai satu kesatuan fisis. Secara fisis, zona-zona yurisdiksi yang dibuat oleh manusia seringkali tidak sesuai dengan ekosistem kelautan yang ada. Oleh karena itu, diperlukan kerja sama internasional untuk menyelesaikan permasalahanpermasalahan lintas batas zona yurisdiksi (Tanaka, 2015).

The United Nations Convention on the Law of the Sea (UNCLOS) merupakan perjanjian internasional yang ditandatangani pada tahun 1982. Perjanjian internasional ini berisi sekumpulan aturan atas laut di bumi termasuk tata mengelola sumber daya di dalam nya. UNCLOS 1982 hadir untuk mengevaluasi legal framework atas Hukum Laut yang telah terbentuk melalui konferensi Jenewa tahun 1958.

Indonesia merupakan salah satu negara yang tunduk pada dasar hukum laut internasional yang lazim disebut UNCLOS 1982. UNCLOS 1982 merupakan hasil dari berbagai konferensi PBB yang membahas tentang hukum laut dan berlangsung sejak tahun 1973-1982. Hingga kini, tak kurang dari 158 negara yang telah menyatakan persetujuan terhadap konvensi tersebut, termasuk Uni Eropa. Dengan adanya UNCLOS 1982, Indonesia berhasil memperoleh pengakuan resmi masyarakat internasional atas konsep Negara Kepulauan yang telah diperjuangkan Indonesia selama 25 tahun secara terus menerus. Menurut UNCLOS 1982, Negara Kepulauan adalah suatu negara yang seluruhnya terdiri dari satu atau lebih gugusan kepulauan dan dapat mencakup pulau-pulau lain. Negara Kepulauan dapat menarik garis dasar/pangkal lurus kepulauan yang menghubungkan titik-titik 
terluar pulau-pulau dan karang kering terluar kepulauan itu.

Sebagai salah satu negara yang tunduk pada UNCLOS 1982, Indonesia juga telah melakukan ratifikasi (persetujuan hukum internasional) terhadap konvensi tersebut, yaitu dengan melakukan pengesahan terhadap Undang-Undang Nomor 17 Tahun 1985, tepatnya pada tanggal 31 Desember 1985 di Jakarta. Dalam Undang-Undang Nomor 17 Tahun 1985 dinyatakan bahwa Zona Ekonomi Eksklusif (ZEE) merupakan zona laut yang lebarnya tidak melebihi 200 mil laut dihitung dari garis dasar/pangkal dari mana lebar Laut Teritorial diukur.

Dasar hukum lain, yaitu UndangUndang Nomor 5 Tahun 1983 yang disahkan di Jakarta pada tanggal 18 Oktober 1983, mengatur tentang Zona Ekonomi Eksklusif Indonesia (ZEEI) dan merupakan tindak lanjut atas dikeluarkannya Pengumuman Pemerintah Republik Indonesia tentang Zona Ekonomi Eksklusif Indonesia pada tanggal 21 Maret 19880. Dalam Undang-Undang Nomor 5 Tahun 1983 dimuat definisi Zona Ekonomi Eksklusif Indonesia, di mana Zona Ekonomi Eksklusif Indonesia adalah jalur di luar dan berbatasan dengan laut wilayah Indonesia sebagaimana ditetapkan berdasarkan undang-undang yang berlaku tentang perairan Indonesia yang meliputi dasar laut, tanah di bawahnya dan air di atasnya dengan batas terluar 200 (dua ratus) mil laut diukur dari garis pangkal laut wilayah Indonesia. Dalam Undang-Undang Nomor 5 Tahun 1983 juga dimuat hak berdaulat, hak-hak lain, yurisdiksi, dan kewajibankewajiban yang perlu diperoleh dan dilaksanakan Indonesia atas Zona Ekonomi Eksklusif Indonesia.

Berbagai hak dan kewajiban yang dimiliki Indonesia meliputi hak berdaulat untuk melakukan eksplorasi dan eksploitasi, pengelolaan dan konservasi sumber daya alam hayati dan non hayati dari dasar laut dan tanah di bawahnya serta air di atasnya dan kegiatan-kegiatan lainnya untuk eksplorasi dan eksploitasi ekonomis zona tersebut, seperti pembangkitan tenaga dari air, arus dan angin; yurisdiksi yang berhubungan dengan pembuatan dan penggunaan pulaupulau buatan, instalasi-instalasi dan bangunan-bangunan lainnya, penelitian ilmiah mengenai kelautan, perlindungan dan pelestarian lingkungan laut; serta hakhak lain dan kewajiban-kewajiban lainnya yang didasarkan pada Konvensi Hukum Laut yang berlaku. Pada kondisi terkini, Konvensi Hukum Laut yang berlaku adalah UNCLOS 1982.

Pengelolaan sumber daya alam hayati di Zona Ekonomi Eksklusif juga diketahui memiliki dasar hukum terpisah, yaitu Peraturan Pemerintah Nomor 15 Tahun 1984 yang secara umum membahas tentang ketentuan umum, pemanfaatan, konservasi, perizinan, serta ketentuan pidana dan pencabutan izin. Dalam Peraturan Pemerintah Nomor 15 Tahun 1984 dinyatakan bahwa orang atau badan hukum asing dapat diberi kesempatan untuk melakukan penangkapan ikan di Zona Ekonomi Eksklusif Indonesia sepanjang orang atau badan hukum Indonesia yang bergerak dibidang usaha perikanan Indonesia belum dapat sepenuhnya memanfaatkan jumlah tangkapan yang diperbolehkan berdasarkan data hasil penelitian, survei, evaluasi dan/atau hasil kegiatan penangkapan ikan. Orang atau badan hukum tersebut juga harus terlebih dahulu memperoleh izin dan akan dikenakan pungutan perikanan dari Pemerintah Republik Indonesia.

Di Zona Ekonomi Eksklusif Indonesia, Indonesia mengakui kebebasan pelayaran dan penerbangan internasional serta kebebasan pemasangan kabel dan pipa bawah laut yang sesuai dengan prinsip-prinsip hukum laut internasional 
yang berlaku. Peraturan Presiden Nomor 16 Tahun 2017 (khususnya Bab II) dan Undang-Undang Nomor 32 Tahun 2014 juga menyatakan hal-hal terkait wilayah perairan, hak berdaulat, Kawasan yurisdiksi, serta laut lepas, dan kawasan dasar laut internasional yang isinya selaras dengan kedua undang-undang yang telah dijelaskan sebelumnya.

Hak Lintas dalam pelaksanaan kebebasan pelayaran dan penerbangan internasional dimuat secara lengkap dalam Undang-Undang Nomor 6 Tahun 1996 tentang Perairan Indonesia. Terdapat dua jenis hak lintas, yaitu hak lintas alur laut kepulauan dan hak lintas transit. Terkait hak lintas alur laut kepulauan dinyatakan bahwa segala jenis kapal dan pesawat udara negara asing, baik negara pantai maupun negara tak berpantai, menikmati hak lintas alur laut kepulauan melalui perairan kepulauan Indonesia, antara satu bagian dari laut lepas atau Zona Ekonomi Eksklusif Indonesia dengan bagian laut lepas atau Zona Ekonomi Eksklusif Indonesia lainnya. Sementara itu, terkait hak lintas transit dinyatakan bahwa semua kapal dan pesawat udara asing mempunyai kebebasan pelayaran dan penerbangan semata-mata untuk tujuan transit yang terus-menerus, langsung dan secepat mungkin melalui laut teritorial Indonesia di selat antara satu bagian laut atau Zona Ekonomi Eksklusif Indonesia dan bagian laut lepas atau Zona Ekonomi Eksklusif Indonesia lainnya. Kedua jenis hak lintas tersebut harus dilaksanakan sesuai dengan ketentuan konvensi, hukum internasional lainnya, dan/atau peraturan perundangundangan yang berlaku.

Secara internasional, kedaulatan teritorial suatu negara diatur dalam konvensi PBB tentang hukum laut UNCLOS 1982 (United Nation Convention Law of The Sea). Berdasar peraturan yang ada dalam UNCLOS Pasal 56 ayat (1), Indonesia memiliki undang - undang tentang hak berdaulat NKRI di wilayah ZEE. Peraturan ini ada dalam Pasal 4 ayat (1) Undang Undang Nomor 5 Tahun 1983 tentang Zona Ekonomi Eksklusif. Pada pemberlakuannya, UNCLOS adalah hukum tertinggi terkait hukum laut. Semua hukum laut yang ada pada peraturan masing masing negara pada umumnya didasarkan atas peraturan - peraturan yang ada dalam UNCLOS.

Bertentangan dengan UNCLOS 1982, Cina melakukan klaim sepihak terhadap hak eksploitasi di Laut Natuna Utara dengan alasan bahwa nelayan Tiongkok telah lama beraktivitas di sana. Namun klaim ini tidak berdasar karena bersifat sangat unilateral dan tidak berdasar hukum apapun. Klaim yang hingga saat ini tidak diakui oleh dunia internasional.

Jika suatu negara hendak mengajukan klaim atas suatu wilayah, peraturan yang seharusnya dijadikan acuan adalah UNCLOS 1982. Setelah klaim diajukan lalu akan diadakan perundingan antara negara - negara yang terlibat baik bilateral maupun multilateral untuk didapatkan kesepakatan yang akan dituangkan dalam perjanjian tertulis.

\section{METODE PENELITIAN}

Metode kami gunakan adalah metode studi literatur. Teknik ini dilakukan dengan cara membaca, mempelajari, dan mengkaji literatur-literatur yang berhubungan dengan budaya demokrasi konstitusional, pendidikan kewarganegaraan, dan model school-based democracy education. Faisal (2008:30) mengemukakan bahwa hasil studi literatur bisa dijadikan masukan dan landasan dalam menjelaskan dan merinci masalah-masalah yang akan diteliti; termasuk juga memberi latar belakang mengapa masalah tadi penting diteliti. Dengan metode ini, peneliti berharap agar sumber-sumber literatur yang dikaji dapat memenuhi dan melengkapi data-data yang 
dibutuhkan. Sumber literatur utama yang akan digunakan adalah hukum-hukum yang berkaitan dengan pembatasan wilayah maupun hal lainnya yang bersinggungan dengan konflik Laut Natuna.

\section{HASIL PENELITIAN DAN PEMBAHASAN Hasil Penelitian}

Negara China mengklaim bahwa laut yang berada di tepi Samudra Pasifik dan membentang dari Selat Karimata dan Selat Malaka hingga Selat Taiwan adalah laut milik mereka dengan nama Laut Tiongkok Selatan (South China Sea) (IHO, 1953) (Nurgiansah, 2018). Klaim ini dilakukan atas dasar "nine-dash line", suatu garis yang didefinisikan berdasarkan teritori historis negara Tiongkok. Apabila dilihat secara historis, negara Tiongkok merupakan negara pertama yang menemukan pulau-pulau yang berada di Laut Tiongkok Selatan.

Dalam dokumen Yi Zhou Su (Shen, 2003), dikatakan bahwa pulau-pulau yang berada di Laut Tiongkok Selatan sudah menjadi destinasi masyarakat China untuk melakukan ekspedisi serta target penaklukan pada masa Dinasti Zhou Timur. Di era ini, Laut Tiongkok Selatan dikenal dengan sebutan Nan Hai (The South Sea) oleh para pemimpin China. Nan Hai kemudian diubah ketika memasuki Dinasti Han Timur. Pada era ini, nama Nan Hai diubah menjadi Zhanghai Qitou, yang berarti South China Sea atau Laut Tiongkok Selatan. Nama ini kemudian digunakan secara terus menerus hingga akhirnya pada tahun 1983, Chinese Place Name Commission mempublikasikan nama-nama untuk berbagai macam pulau, terumbu karang, serta tepian di Laut Tiongkok Selatan. Nama Laut Tiongkok Selatan ini juga dipublikasikan oleh International Hydrographic Organization pada tahun 1953 sehingga nama Laut Tiongkok Selatan atau South China Sea menjadi cukup kuat di negara China. Penemuan ini mempengaruhi masyakarat China untuk percaya bahwa Laut Tiongkok Selatan merupakan bagian dari negara China sejak jaman Dinasti Xia hingga jaman Dinasti Qing.

Dengan klaim yang diajukan China atas Laut Tiongkok Selatan dan pulau pulau yang termasuk dalam jangkauan Nine Dash Line ini, maka jalur perdagangan besar yang melewati laut ini juga termasuk dalam klaim Republik Rakyat Cina atas wilayah ini. Menurut data yang didapatkan pada tahun 2016, Laut Cina Selatan dilintasi oleh perdagangan senilai 3,4 miliar dollar. Jika klaim China atas wilayah dalam nine dashed line dikabulkan, maka seluruh hak ekonomi dan hak berkuasa atas daerah ini akan sepenuhnya berada dalam tangan pemerintah China (Nurgiansah, 2019).

Seiring dengan adanya Nine Dash Line yang diterbitkan oleh China, China juga melakukan upaya militer di daerah tersebut. China membuat pangkalan militer untuk menguatkan klaimnya. China melakukan penyebaran pesawat peringatan dan kontrol Angkatan Udara China (PLA) KJ-500, ke daerah Kepulauan Spratly, salah satu daerah yang diklaim China dalam Nine Dash Line.

Selain upaya militer, pemerintah China juga melakukan upaya non militer untuk memperkuat klaim mereka akan Laut China Selatan. Anthe Roberts dalam bukunya, Is International Law International? mengatakan bahwa pemerintah China mendanai riset-riset yang berkaitan dengan hukum laut, terutama yang menyinggung permasalahan Laut China Selatan. Upaya-upaya lain yang dilakukan China adalah dengan melakukan familiarisasi Nine Dash Line pada komunitas internasional. Salah satunya adalah dengan memasukan Nine Dash Line pada bagian belakang paspor China. 
Menanggapi tindakan yang dilakukan China dalam melakukan klaim atas Laut China Selatan, pemerintah Indonesia melakukan berbagai pendekatan untuk menegakan kedaulatan di wilayah tersebut. Strategi kebijakan pertahanan dalam menjaga wilayah kedaulatan teritorial yang digunakan Pemerintah Indonesia bersifat soft defense. Cara Indonesia untuk menjalankannya adalah dengan menggunakan diplomasi pertahanan maritim. Hal ini dilakukan karena adanya pergeseran akibat penekanan dari internasional tentang kebijakan pertahanan dari pencegahan menuju keamanan kooperatif teritorial. Keamanan kooperatif teritorial diwujudkan dengan cara diplomasi pertahanan maritim tersebut (Adikara dan Munandar, 2021) (Nurgiansah, 2020).

Diplomasi Pertahanan Maritim Bilateral dilakukan dengan cara pertukaran informasi intelijen dalam bidang keamanan maritim, patroli bersama, dan latihan bersama. Upaya Diplomasi Pertahanan Maritim Hukum Internasional yang dilakukan Indonesia adalah mengingatkan Tiongkok dan negara-negara lain yang berusaha masuk wilayah kedaulatan Indonesia tanpa izin dengan mengacu pada UNCLOS 1982 pasal 49 ayat 1 dan 4 . Menteri Luar Negeri Indonesia juga telah memberikan peringatan dalam bentuk konferensi internasional terkait batas wilayah Laut Natuna Utara. Indonesia sudah melakukan berbagai upaya sebagai bentuk diplomasi pertahanan maritim Indonesia. Cara yang dilakukan seperti mengikuti latihan bersama, patroli gabungan, peningkatan kerja sama pertahanan, dan peringatan dengan dasar UNCLOS 1982 untuk mempertahankan kedaulatannya (Adikara dan Munandar, 2021).

Permasalahan utamanya sekarang adalah terkait dengan kerasnya upaya penolakan Tiongkok terhadap aturan perbatasan Indonesia dan bahkan hukum laut internasional, terutama terkait dengan adanya kebijakan One Belt One Road (OBOR) dan klaim sepihak nine dash line. Upaya perlawanan secara diplomatis kerap kali tidak membuahkan hasil yang maksimal sehingga dilakukan upaya pelawanan dalam bentuk militer.

Sebagai upaya militer, pemerintah menggerakkan beberapa KRI, pesawat tempur, pesawat pengintai strategis, dan Satuan Operasional TNI lainnya ke Pulau Natuna atas perintah langsung Panglima TNI untuk melaksanakan operasi siaga tempur laut di perairan ZEE Indonesia Laut Natuna Utara dan sekitarnya. Adapun strategi umum yang mungkin ditempuh oleh TNI, antara lain penggunaan kekuatan operasional TNI didasarkan pada prinsip jika Cina juga telah menggerakkan kekuatan militernya (kapal perang atau pesawat tempur China telah digerakkan). Mengedepankan penerapan aturan-aturan dalam UNCLOS 82 dan hukum Internasional lainnya yang berlaku, sehingga apabila terjadi eskalasi konflik dengan Cina, penyelesaian masalahnya tetap dalam kerangka sengketa hukum Internasional. Kedua adalah membangun semangat personel TNI yang bertugas sebagai satgas tempur terdepan, dan juga menjamin ketersediaan dukungan sumber daya nasional yang memadai untuk menghadapi segala kemungkinan eskalasi konflik yang mungkin dilakukan oleh militer Cina.

Kepemilikan atau hak negara terhadap wilayah laut telah ada diatur sejak tahun 1958 yaitu dengan dibentuknya UNCLOS I (1958) (Nurgiansah, 2021), UNCLOS II (1960) dan yang terakhir Konvensi PBB tentang hukum laut 1982 (UNCLOS 1982) dengan memunculkan delapan zonasi pengaturan (regime) hukum laut yaitu: perairan pedalaman, perairan kepulauan, termasuk dalamnya selat yang digunakan untuk 
pelayaran internasional, zona tambahan, zona ekonomi eksklusif, landas kontinen, dan kawasan dasar laut internasional.

\section{Pembahasan}

Persengketaan di Laut Cina Selatan ini sebenarnya tidak hanya dihadapi oleh Indonesia. Namun, beberapa negara di Asia Tenggara juga terdampak kerugian dari klaim sepihak oleh China, di antaranya adalah Malaysia, Brunei Darussalam, Vietnam, dan Filipina. Terutama karena di Laut Cina Selatan terdapat dua kepulauan besar yaitu Spratly dan Paracel (Partogi, 2013). Untuk melawan klaim sepihak dari RRT ini, negara-negara ASEAN sudah sepakat untuk memakai UNCLOS sebagai dasar hukumnya. Terkhusus permasalahan yang dibahas pada analisis, pembahasan ini hanya berfokus pada persengketaan Indonesia dan China. Beberapa pasal UNCLOS yang berkaitan dengan permasalahan ini di antaranya:

1. Pasal 2 UNCLOS 1982

Diatur mengenai hak penerbangan di laut teritorial bahwa: "Kedaulatan suatu negara pantai selain wilayah daratan dan perairan pedalamannya dan, dalam hal suatu negara kepulauan, perairan kepulauannya meliputi pula suatu jalur laut yang berbatasan dengannya yang dinamakan laut teritorial. Kedaulatan ini meliputi ruang udara di atas laut teritorial serta dasar laut dan tanah di bawahnya."

2. Pasal 51 UNCLOS 1982

Mengatur Traditional Fishing Rights, dan berbunyi "Tanpa mengurangi arti dan maksud dari Pasal 49, bahwa negara kepulauan harus menghormati perjanjian yang ada dengan negara lain dan harus mengakui hak perikanan tradisional dan kegiatan lain yang sah di negara tetangga yang langsung berdampingan dalam daerah tertentu yang berada di dalam perairan kepulauan. Syarat dan ketentuan bagi pelaksana hak dan kegiatan yang demikian yang termasuk dengan sifatnya, ruang lingkup dan daerah dimana hak dan kegiatan tersebut berlaku atas permintaan salah satu negara yang bersangkutan harus diatur dengan melakukan perjanjian antara negara-negara yang terkait. Hak itu tidak boleh dialihkan atau dibagi dengan negara ketiga ataupun warga negaranya tersebut."

3. Pasal 58 UNCLOS 1982

Di zona ekonomi eksklusif, semua Negara, baik Negara berpantai atau tak berpantai, menikmati dengan tunduk pada ketentuan yang relevan Konvensi ini, kebebasan pelayaran dan penerbangan, serta kebebasan meletakkan kabel dan pipa bawah laut yang disebut dalam pasal 87 dan penggunaan laut lain yang sah menurut hukum internasional yang bertalian dengan kebebasankebebasan ini, seperti penggunaan laut yang berkaitan dengan pengoperasian kapal, pesawat udara, dan kabel serta pipa di bawah laut, dan sejalan dengan ketentuan-ketentuan lain Konvensi ini. Pasal 88 sampai 115 dan ketentuan hukum internasional lain yang berlaku diterapkan bagi zona ekonomi eksklusif sepanjang tidak bertentangan dengan Bab ini.

4. Pasal 59 UNCLOS 1982

Dalam hal dimana Konvensi ini tidak memberikan hak-hak atau yurisdiksi kepada negara pantai atau kepada negara lain di zona ekonomi eksklusif, dan timbul sengketa antara kepentingan-kepentingan negara pantai dan negara lain atau negaranegara lain manapun, maka sengketa itu harus diselesaikan berdasarkan keadilan dan dengan pertimbangan segala keadaan yang relevan, dengan memperhatikan masing-masing keutamaan kepentingan yang terlibat 
bagi para pihak maupun bagi masyarakat internasional secara keseluruhan.

5. Pasal 76 UNCLOS 1982

Mengenai Landas Kontinen, "batas terluar landas kontinen suatu negara pantai dinyatakan sampai kedalaman 200 mil laut atau diluar batas itu sampai kedalaman air yang memungkinkan dilakukannya eksplorasi dan eksploitasi sumber daya alam"

6. Pasal 289 UNCLOS 1982

Penentuan penetapan batas wilayah, "penetapan batas wilayah sebaiknya dengan melakukan perjanjian internasional yang disepakati negaranegara, dan penggunaan hak sejarah dapat digunakan asalkan tidak mendapat pertentangan dari negara lain."

7. Pasal 279, 280, 283, dan 287 UNCLOS 1982

Pasal-pasal tersebut menjelaskan mengenai kewajiban dari setiap pihak yang bertikai untuk menyelesaikan sengketa dengan cara-cara yang damai.

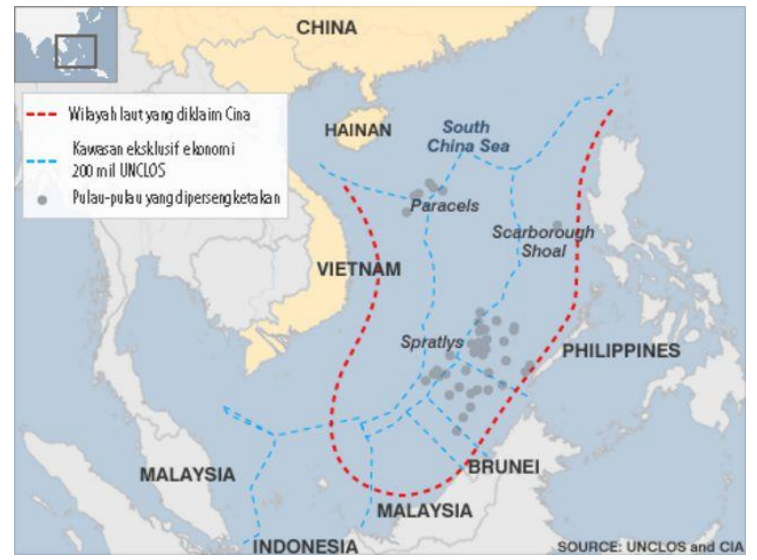

Gambar 1.

Kelayakan China untuk mengklaim seluruh wilayah Laut Cina Selatan harus diuji berdasarkan pasal-pasal UNCLOS 1982 yang telah diakui resmi secara internasional. Berdasarkan Pasal 58 yang mengatur tentang ZEE dan Pasal 76 yang mengatur tentang Landas Kontinen, negara pemegang hak tersebut bebas untuk mengeksploitasi sumber daya laut di dalam batasnya, dan negara lain wajib tunduk atas negara pemegang hak ZEE dan Landas Kontinen. Jika dilihat dari jarak garis pantai RRT dengan perairan Natuna Utara, tentu sudah jauh melebihi ZEE dan landas kontinen yang dimiliki oleh RRT, sehingga RRT tidak layak untuk mengklaim wilayah perairan Natuna Utara.

China membuat klaim sepihak atas kepemilikan Laut Cina Selatan hanya atas dasar kepercayaan dari sistem pada zaman dinasti yaitu "Traditional Fishing Ground". Padahal, sistem tersebut tidak diakui oleh UNCLOS 1982. Yang diatur dan diakui di dalam UNCLOS 1982 hanyalah "Traditional Fishing Rights" yang tercantum pada Pasal 2. Menurut UNCLOS 1982, Traditional Fishing Rights dan Traditional Fishing Ground saling berhubungan. Traditional Fishing Rights hanya dimiliki oleh negara yang berdampingan langsung dengan negara kepulauan dimana wilayah yang menjadi perairan kepulauan dulunya merupakan daerah penangkapan ikan oleh nelayan dari negara tetangga tersebut. Tindakan klaim atas fishing ground oleh China dilakukan dengan memasuki kapal nelayan China ke dalam ZEE Indonesia tepatnya di perairan Natuna dengan dikawal oleh kapal coast guard. Atas klaim ini, China merasa bahwa memiliki fishing ground atau kepemilikan dari wilayah ZEE tersebut dan memasuki Laut Natuna Utara tanpa izin karena menganggap kepulauan Natuna sebagai bagian dari wilayah kedaulatan dan perairannya.

Klaim berdasarkan sejarah yang digunakan oleh RRT sebenarnya diperbolehkan saja dalam UNCLOS Pasal 289, namun dengan syarat bahwa klaim tersebut tidak menimbulkan sengketa dengan negara lain. Pada kenyataannya, sudah banyak negara yang bersengketa akibat klaim sepihak China ini. Sehingga 
lagi-lagi, China melanggar hukum perairan UNCLOS. Persengketaan terhadap ZEE ini harus dilakukan secara damai selaras dengan bunyi pada Pasal ke 59.

\section{KESIMPULAN}

Klaim China atas wilayah Laut China Selatan tidaklah valid. Hal ini disebabkan oleh melalui klaim tersebut, China melakukan pelanggaran atas beberapa pasal yang ada pada UNCLOS yang diakui secara internasional. Komunitas internasional telah mengakui kedaulatan wilayah Indonesia di Laut China Selatan dengan batas-batas wilayah berupa zona landas kontinen dan ZEE yang telah ditetapkan sebelumnya. Oleh karena itu, aktivitas China di Laut China Selatan merupakan pelanggaran tersendiri terhadap peraturan internasional dalam hal ini beberapa pasal pada UNCLOS, seperti yang telah disebutkan di atas. Selain itu, aktivitas China di wilayah Indonesia juga merupakan pelanggaran tersendiri terhadap kedaulatan Indonesia. Indonesia memiliki hak atas kedaulatan wilayahnya di Laut China Selatan dan pengelolaan sumber daya di dalamnya, sesuai dengan peraturan perundangundangan yang dimiliki oleh Indonesia yang merupakan hasil ratifikasi dari aturan-aturan yang berlaku secara internasional.

\section{DAFTAR PUSTAKA}

Adikara, A. P. B. dan Adis Imam Munandar. (2021). Tantangan Kebijakan Diplomasi Pertahanan Maritim Indonesia dalam Penyelesaian Konflik Laut Natuna Utara. Jurnal Studi Diplomasi dan Keamanan, 13(1), 83-101

B., Adhi Pramana. (2017). Pelanggaran Zona Ekonomi Eksklusif di Perairan Natuna dalam Perspektif Hukum Laut Internasional. Skripsi Fakultas Hukum Universitas Sumatera Utara

Deni, Fitra dan Lukman Sahari. (2017). Upaya Diplomasi Indonesia Terhadap Klaim China Atas Zona Ekonomi Eksklusif Indonesia di Laut Natuna. International \& Diplomacy, 3(1), $1-22$.

Ernawati. Implementasi Deklarasi Djuanda dalam Perbatasan Perairan Lautan Indonesia. Kajian Multi Disiplin Ilmu untuk Mewujudkan Poros Maritim dalam Pembangunan Ekonomi Berbasis Kesejahteraan Rakyat.

Fatmawati, A. dan Elsa Aprina. (2019). Keabsahan Alasan Penolakan Republik Rakyat Tiongkok Terhadap Putusan Permanent Court Arbitration Atas Sengketa Klaim Wilayah Laut Cina Selatan Antara Filipina dan Republik Rakyat Tiongkok Berdasarkan Hukum Internasional. VeJ, 5(1), 105-129.

International Hydrographic Organization, 1953, Limits of Ocean and Seas

Muslimah, F., Wazi'atus Santiyah, dan Depict Pristine Adi. (2020). Analisis Konflik Kepulauan

Natuna Pada Tahun 2016 - 2019. Jurnal Hukum Pidana Islam, 2(2), 87-96

Nurgiansah, T. H. (2018). Pengembangan Kesadaran Hukum Berlalu Lintas Siswa Melalui Model Pembelajaran Jurisprudensial Dalam Pendidikan Kewarganegaraan (Studi Kasus di SMK Bina Essa Kabupaten Bandung Barat Kelas X Administrasi Perkantoran). Tesis. Repository Universitas Pendidikan Indonesia, Oktober. http://ieeeauthorcenter.ieee.org/wp-content/uploads/IEEE-ReferenceGuide.pdf\%0Ahttp://wwwlib.murdoch.edu.au/find/citation/ieee.html\%0Ahttps://doi.or g/10.1016/j.cie.2019.07.022\%0Ahttps://github.com/ethereum/wiki/wiki/White-

Paper\%0Ahttps://tore.tuhh.de/hand

Nurgiansah, T. H. (2019). Pemutakhiran Kurikulum Pendidikan Kewarganegaraan di Era 
Revolusi Industri 4.0. Prosiding Seminar Kewarganegaraan Universitas Negeri Medan, 1(1), 95-102.

Nurgiansah, T. H. (2020). Filsafat Pendidikan. In Banyumas: CV Pena Persada.

Nurgiansah, T. H. (2021). Pendidikan Pancasila. In Solok: CV Mitra Cendekia Media.

Peraturan Pemerintah Republik Indonesia Nomor 15 Tahun 1984 tentang Pengelolaan Sumber Daya Alam Hayati di Zona Ekonomi Eksklusif Indonesia

Peraturan Presiden Republik Indonesia Nomor 16 Tahun 2017 tentang Kebijakan Kelautan Indonesia

Prakasa, S. U. W. dan Al-Qodar Purwo. (2019). Analisis Historical Traditional Fishing Right pada Zona Ekonomi Eksklusif (ZEE) Indonesia. Legality, 27(1), 83-97.

Priskila, K. dan Athina Kartika Sari. (2021). Tinjauan Yuridis Pengaruh Pengakuan Sepihak China Atas Zona Ekonomi Eksklusif Laut Natuna Utara Berdasarkan Hukum Internasional. Jurnal Komplikasi Hukum, 6(1), 2-16.

Rahardjo, M. D. (2003). Evaluasi dan Dampak Amandemen UUD1945 Terhadap Perekonomian di Indonesia. UNISIA, 49(26), 240-246

Ramli, R. P. (2021). Sengketa Republik Indonesia - Republik Rakyat Tiongkok di Perairan Natuna. Hasanuddin Journal of International Affairs, 1(1), 20-35

Santoso, T. I. (2020). Aksi Agresivitas Cina Pada Zona Ekonomi Eksklusif Indonesia Laut Natuna Utara: Perspektif Tugas Pokok TNI. Jurnal Kajian Lemhamnas RI, 41, 35-46

Shen, Jianming. (2002). China's Sovereignty over the South China Sea Islands: A Historical Perspective. Chinese JIL, 94-157

Syah, Taufiqurrohman. (2009). Amandemen UUD Negara RI Tahun 1945 Menghasilkan Sistem Checks And Balances Lembaga Negara. Karya Tulis Biro Rekrutmen, Advokasi dan Peningkatan Kapasitas Hukum

Tampi, Butje. (2017). Konflik Kepulauan Natuna Antara Indonesia Dengan China (Suatu Kajian Yuridis). Jurnal Hukum Unsrat, 23(10), 1-16

Tanaka, Yoshifumi, 2015, The International Law of the Sea, Inggris: T.J. International Ltd. Padstow Cornwall

Undang-Undang Nomor 17 Tahun 1985 tentang Pengesahan Konvensi Perserikatan BangsaBangsa Tentang Hukum Laut

Undang-Undang Nomor 32 Tahun 2014 tentang Kelautan

Undang-Undang Nomor 4 Prp Tahun 1960 tentang Perairan Indonesia

Undang-Undang Nomor 5 Tahun 1983 tentang Zona Ekonomi Eksklusif Indonesia.

Undang-Undang Nomor 6 Tahun 1996 tentang Perairan Indonesia

United Nations Convention on the Law of the Sea (UNCLOS) 